\title{
Production of L-glutaminase From Agro-industrial Waste by Halomonas Elongata MM-5 Under Solid State Fermentation
}

\section{Mohammed Mujahed ( $\sim$ mdmujahed483@gmail.com)}

Department of Biotechnology, COCSIT, Latur-413531, M.S. India. https://orcid.org/0000-0001-84124948

\section{Dhiraj G Jirgale}

Department of Biotechnology, COCSIT, Latur-413531, M.S., India.

\section{Basavraj M Kareppa}

Department of Biotechnology, D.S.M. College, Parbhani-431401, M.S., India

\section{Research Article}

Keywords: L-glutaminase, extremely halotolerant, Halomonas elongata, red gram husk, moisture content, solid state fermentation

Posted Date: August 9th, 2021

DOl: https://doi.org/10.21203/rs.3.rs-648562/v1

License: (9) This work is licensed under a Creative Commons Attribution 4.0 International License. Read Full License 


\section{Abstract}

In this study L-glutaminase production by extremely halotolerant Halomonas elongata MM-5 using solidstate fermentation was investigated. Screening of a variety of agro-industrial byproducts such as rice husk, green gram husk, bengal gram husk, red gram husk, safflower oil cake, groundnut oil cake, black gram husk, groundnut skin and wheat bran was carried out individually and in different combinations. Optimization of various physicochemical parameters namely incubation time, $\mathrm{pH}$, temperature, initial moisture content, carbon sources, nitrogen sources, L-glutamine concentration and inoculum level was carried out. Among the various substrates screened individually red gram husk supported the maximum production of enzyme $79.03 \pm 0.49 \mathrm{lU} / \mathrm{gds}$. In the mixture of substrates screened red gram husk and bengal gram husk in the ratio (60:40) showed maximum $92.06 \pm 1.42 \mathrm{IU} / \mathrm{gds}$ enzyme production. The Lglutaminase production was maximum after 4 days of incubation period, $\mathrm{pH} 8$, temperature $40^{\circ} \mathrm{C}$ and 80 percent moisture content. The lactose and malt extract used as carbon and nitrogen sources respectively supported the maximum yield of L-glutaminase. After screening and optimization of various parameters, the yield of L-glutaminase increased from 79.03 to $159.12 \mathrm{lU} / \mathrm{gds}$.

\section{Introduction}

An abundant quantity of agro-industrial waste is produced annually and its disposal creates a major problem. Management of this waste is crucial because it causes a significant hazard to the surrounding environment. After the harvesting process, the different agricultural residues left are either stored as heaps in the field or burned on-site which causes pollution of air and also influences the quality of soil (Bajar et al. 2020). The agro-industrial waste is highly nutritious and supports the growth of various microorganisms (Ravindran et al. 2018). The solid waste of agro-industrial origin can be availed as a potential substrate for the production of different industrially noteworthy products such as several enzymes, chemicals, animal feed and biofuel (Mohana et al. 2008; Mathioudakis et al. 2017).

Solid state fermentation (SSF) is an efficient process for the valorization of wastes. SSF is a very significant process in terms of high product formation, low usage of energy and solving wastes disposition issues (Botella et al. 2007; Yazid et al. 2017; Marzo et al. 2019). The process of SSF is carried out by growing the microbes in the non-existence or close to the non-existence of free water on wet solid substrates that provide support and nutrients for the microbial growth (Pandey 2003; Hölker and Lenz 2005).

The major parameters which influence the synthesis of enzymes by microorganisms in an SSF process are the choice of appropriate substrate, substrate particle size, substrate moisture content, microorganism and inoculum concentration. Therefore it consists of screening of various agro-industrial byproducts for the microbes growth and synthesis of products (Sodhi et al. 2005).

L-glutaminase (EC. 3.5.1.2) is an important enzyme that catalyzes the hydrolysis of the amide bond in the 
side chain of L-glutamine and produces L-glutamic acid and ammonia and is present in nearly all organisms (Mosallatpour et al. 2019).

L-glutaminase is the key enzyme in the food industry which is responsible for producing umami taste in several oriental fermented foods like soy sauce, sufu, miso (Nandakumar et al. 2003). The most desirable property of L-glutaminases in food sector applications is their salt tolerance as the oriental food products fermentations are carried out under high concentrations of salt (Amobonye et al. 2019).

This study is the first communication of L-glutaminase bioprospected from the Halomonas elongata which is an extremely halotolerant salt pan isolate with the best of our information collected from many peer-reviewed published work.

\section{Materials And Methods}

\section{Microorganism and inoculum preparation}

The extremely halotolerant Halomonas elongata MM-5 (Accession No: MT039456.1) isolated from the salt pan was used in this investigation. The pure culture of Halomonas elongata MM-5 was maintained on slants on media consisting of glucose - 5.0, L-glutamine-5.0, $\mathrm{Na}_{2} \mathrm{HPO}_{4}-6, \mathrm{KH}_{2} \mathrm{PO}_{4}-3, \mathrm{MgSO}_{4} ; 7 \mathrm{H}_{2} \mathrm{O}-$ $0.49, \mathrm{CaCl}_{2}-0.01, \mathrm{NaCl}-50$, Agar-20 g/L of pH-8. The slants after streaking were incubated at $37^{\circ} \mathrm{C}$ for 72 $\mathrm{h}$ in static condition for the growth of isolate and were kept at $4^{\circ} \mathrm{C}$ in the refrigerator until further use. The development of inoculum was done in $250 \mathrm{ml}$ Erlenmeyer flask containing $100 \mathrm{ml}$ of sterile aforementioned medium $(\mathrm{pH}-8)$ and incubated at $37^{\circ} \mathrm{C}$.

\section{Collection of substrates}

Abundantly available various agro-industrial byproducts including rice husk $(\mathrm{RH})$, bengal gram husk $(B G H)$, green gram husk (GGH), red gram husk (RGH), safflower oil cake (SOC), groundnut oil cake (GOC), black gram husk $(\mathrm{BgH})$, groundnut skin (GS) and wheat bran (WB) were collected from the local market and processed.

\section{Screening of various substrates for L-glutaminase production under SSF}

$10 \mathrm{gms}$ of each processed substrate as exclusive production medium was added individually in $250 \mathrm{ml}$ Erlenmeyer flask, moisturized with distilled water (60\%), mixed thoroughly, sterilized by autoclaving at $121^{\circ} \mathrm{C}$ for 20 minutes, cooled at room temperature (RT) and inoculated. After inoculation, the flasks were kept for fermentation at $37^{\circ} \mathrm{C}$ in an incline position to provide a large surface area (Athira et al. 2014).

\section{Enzyme extraction}

The extraction of the crude enzyme from the fermented substrates was carried out by means of simple contact method (Sathish et al. 2008). In 1:5(w/v) ratio, $0.1 \mathrm{M}$ phosphate buffer of $\mathrm{pH} 7.0$ was added to the fermented solid medium, mixed properly and kept at $150 \mathrm{rpm}$ for $30 \mathrm{~min}$ on a rotary shaker. Later to 
recover the leachate the contents were squeezed in cheesecloth. The process was carried out twice, the extracts were combined and centrifugation was carried out for $15 \mathrm{~min}$ at 10,000 rpm in a cooling centrifuge after it collected the supernatant and used as the crude enzyme.

\section{Enzyme assay}

Nesslerization method was used to determine the activity of L-glutaminase (Imada et al. 1973). In the assay, $500 \mu \mathrm{l}$ of crude enzyme was allowed to react with $500 \mu \mathrm{l}$ of $0.04 \mathrm{M} \mathrm{L-glutamine,} 500 \mu$ l of distilled water and $500 \mu$ of phosphate buffer of $\mathrm{pH} 7.2$ and kept for incubation for 30 minutes at $37^{\circ} \mathrm{C}$. The reaction was terminated by adding $500 \mu \mathrm{l}$ of $1.5 \mathrm{M}$ trichloroacetic acid (TCA). Reaction mixture (100 $\mu$ l) was added to $3.7 \mathrm{ml}$ of distilled water. Nessler's reagent $(200 \mu \mathrm{l})$ was added, allowed to incubate for 15 minutes and optical density was recorded at $450 \mathrm{~nm}$. One international unit of the enzyme was defined as the amount of L-glutaminase that releases $1 \mu$ mole of ammonia under standard assay conditions. Lglutaminase yield was expressed as international units per gram of dry substrate (IU/ gds).

\section{Screening of mixed substrates}

For optimization of the substrate composition different combinations of the substrates were taken in the percents as below.

1) Red gram husk: safflower oil cake (60:40)

2) Red gram husk: groundnut oil cake (60:40)

3) Red gram husk: bengal gram husk (60:40)

4) Red gram husk: groundnut skin (60:40)

5) Red gram husk: safflower oil cake: bengal gram husk (60:20:20)

6) Red gram husk: groundnut skin: bengal gram husk (60:20:20)

7) Red gram husk: wheat bran: bengal gram husk (60:20:20)

8) Red gram husk: groundnut skin: wheat bran: bengal gram husk (40:20:20:20) and

9) Red gram husk alone (100\%).

$10 \mathrm{gms}$ of each above combination of substrates were added separately in $250 \mathrm{ml}$ Erlenmeyer flasks, moisturized with distilled water (60\%), mixed thoroughly and sterilized. After allowing to cool at room temperature (RT), these flasks were inoculated and kept for incubation at $37^{\circ} \mathrm{C}$ in the incline position.

\section{Optimization of various parameters}


The different parameters optimized in the present study were fermentation time, $\mathrm{pH}$, temperature, moisture content (\%), concentration of L-glutamine, effect of carbon sources, nitrogen sources and effect of inoculum volume. The method utilized for the optimization of different process parameters affecting L-glutaminase production under SSF was to assess the influence of a single parameter (Sandhya and Lonsane 1994; Mohammed et al. 2019a).

\section{Incubation period}

The influence of the incubation period on L-glutaminase synthesis under SSF was investigated by incubating the flasks after inoculation for 7 days period and measuring the L-glutaminase production regularly after $24 \mathrm{~h}$ up to 7 days.

\section{Initial pH of the medium}

The influence of initial pH on L-glutaminase synthesis ability of Halomonas elongata MM- 5 was investigated by adjusting the $\mathrm{pH}$ of the solid medium in the range 5-10 with different buffers.

\section{Incubation temperature}

The influence of temperature on L-glutaminase synthesis ability of Halomonas elongata MM-5 under SSF was studied. The active culture of Halomonas elongata MM-5 was inoculated in solid medium and incubated at different temperatures $\left(10-60^{\circ} \mathrm{C}\right)$.

\section{Initial moisture content}

To investigate the influence of the initial moisture content of the solid substrate medium on Lglutaminase yield the substrates were moisturized with different moisture levels in the range of 40$200 \%$. This was carried out by changing the volume of buffer added to moisturize the solid substrates. The prepared flasks were autoclaved, inoculated, mixed thoroughly and kept for incubation at $40^{\circ} \mathrm{C}$ (VivekBabu and Lingappa 2004).

\section{Effect of carbon sources}

To study the influence of carbon sources on L-glutaminase production various carbon sources including glucose, xylose, fructose, maltose, dextrose, lactose and sucrose were screened. These carbon sources were supplemented at $1 \%$ concentration in solid substrate medium (Bhosale et al. 2015).

\section{Effect of nitrogen sources}

The influence of various organic and inorganic nitrogen sources such as beef extract, yeast extract, malt extract, tryptone, skimmed milk, urea, ammonium chloride and ammonium sulphate at $1 \%$ concentration on the yield of L-glutaminase was examined.

\section{Effect of L-glutamine concentration}


The effect of L-glutamine concentration on L-glutaminase synthesis under SSF by Halomonas elongata MM-5 was examined by adding L-glutamine in different concentrations $(0.5-3.0 \% \mathrm{w} / \mathrm{w})$ in the solid medium.

\section{Inoculum Size}

The amount of inoculum which may provide more L-glutaminase yield was analysed. The inoculum size selected for this study ranged from $0.5 \%$ to $5 \%$ (Mohammed et al. 2019b).

\section{Results And Discussion}

\section{Screening of various substrates for L-glutaminase production}

In the present study different substrates were screened for L-glutaminase production under solid state fermentation (Fig. 2). Among the various substrates screened red gram husk showed the highest Lglutaminase production (79.03 $\pm 0.49 \mathrm{lU} / \mathrm{gds})$ followed by groundnut skin $(60.18 \pm 0.78 \mathrm{lU} / \mathrm{gds})$ and bengal gram husk $(56.58 \pm 0.63 \mathrm{IU} / \mathrm{gds})$. The least production of $\mathrm{L}$-glutaminase was recorded in rice husk (14.45 $\pm 1.24 \mathrm{lU} / \mathrm{gds})$.

In the screening process, the production of L-glutaminase differed with type of the agromaterial used as substrate (Fig. 3). This variation may arise due to the different chemical compositions of each selected substrate for the fermentation process. The maximum production of $\mathrm{L}$ - glutaminase with bengal gram husk (2731 IU/gds) and the least with rice husk (644 IU/gds) was previously reported (Satish et al. 2008).

\section{Screening of mixed substrates}

Among the different combinations of substrates screened (Fig. 4), red gram husk and bengal gram husk in the 60:40 combination on dry weight basis yield maximum production of L-glutaminase $(92.06 \pm 1.42 \mathrm{lU} / \mathrm{gds})$, when compared to other combination of substrates and red gram husk $(80.14 \pm 1.22$ $\mathrm{IU} / \mathrm{gds}$ ) alone. Hence a mixture of red gram husk and bengal gram husk in the ratio 60:40 was subsequently utilized as the solid substrate medium for the L-glutaminase production.

Tea dust and green gram as solid substrate in the ratio 1:2 produced maximum L-glutaminase $(285.28$ $\mathrm{U} / \mathrm{gds}$ ) under SSF by Aspergillus wentii when compared to tea dust (248.6 U/gds) and green gram (234.7 U/gds) alone as individual substrates (Amulya and Raju 2014).

\section{Incubation period}

The enzyme production was maximum $103 \pm 0.64 \mathrm{lU} / \mathrm{gds}$ after 4 days ( 96 hours) of incubation period and beyond it increase in the incubation period has resulted in decreased production of L-glutaminase (Fig. 3). The incubation time is a crucial parameter that influences the enzyme production by bacteria. The enzyme synthesis is dependent on the stages of growth of the organism and also the period of 
incubation (Hiremath et al. 2011). Fermentation time was kept as 4 days (96 hours) for further experiments.

\section{Initial pH of the medium}

The growth rate of an organism as well as the yield of enzyme is affected by $\mathrm{pH}$ of the medium and incubation temperature (Bhosale et al. 2011). In this study the influence of $\mathrm{pH}$ on the production of Lglutaminase was evaluated, the yield of the L-glutaminase was maximum $116 \pm 1.44 \mathrm{IU} / \mathrm{gds}$ at pH 8 . After that reduction in the synthesis of the L-glutaminase was recorded (Fig. 6). For further experiments, the initial $\mathrm{pH}$ of the solid substrate medium was set at 8 . Previously by Alcaligenes faecalis KLU102, the maximum synthesis of L-glutaminase was reported at pH 7 (Pandian B 2015).

\section{Incubation temperature}

In this study, the incubation temperature has shown a significant influence on the production of Lglutaminase by Halomonas elongata MM-5 under SSF. The highest L-glutaminase yield was recorded at $40^{\circ} \mathrm{C}$ and least at $60^{\circ} \mathrm{C}$. The yield of L-glutaminase was enhanced with the enhancement in the temperature from 10 to $40^{\circ} \mathrm{C}$ (Fig.7). However, further enhancement in temperature showed less enzyme yield, which may be due to inhibition in the growth of Halomonas elongata MM-5 at high temperatures.

\section{Initial moisture content}

In solid state fermentation the content of moisture is one of the important parameter as it affects the growth, formation and production of various metabolites by microbes. The optimum content of moisture for the growth of microorganisms and substrate utilization by them varies with the substrate and organism used in the SSF process (Saxena and Singh 2011). In this investigation linearity between moisture level and L-glutaminase production was recorded up to 80 percent, and thereafter, an additional rise in moisture level in the solid substrate medium resulted in the decreased L-glutaminase yield (Fig. 8). The maximum L-glutaminase production $127 \pm 1.03 \mathrm{lU} / \mathrm{gds}$ was observed at 80 percent moisture content and minimum $64 \pm 1.71 \mathrm{IU} / \mathrm{gds}$ at 200 percent moisture content.

The maximal L-glutaminase production by Trichoderma koningii was reported at 70 percent moisture level under SSF (ElSayed 2009).

\section{Effect of carbon sources}

The carbon and nitrogen sources influence considerably the growth rate and formation of products in any fermentation medium. The supplementation of additional carbon sources to the solid substrate fermentative medium showed a significant effect on the yield of L-glutaminase by Halomonas elongata MM-5. In the present study, lactose supported the maximal production of enzyme $147 \pm 1.77 \mathrm{IU} / \mathrm{gds}$ followed by fructose, xylose and sucrose (Fig. 9). The least yield of L-glutaminase was recorded in glucose $97 \pm 2.23 \mathrm{IU} / \mathrm{gds}$. These results are in contrast with the results of production of L-glutaminase by Vibrio costicola ACMR267, Zygosaccharomyces rouxii and Trichoderma koningii under SSF where 
glucose has shown the stimulatory influence on the production of L-glutaminase (Prabhu and Chandrasekaran 1997, Kashyap et al 2002 and ElSayed 2009).

\section{Effect of nitrogen sources}

The influence of various additional nitrogen sources on the yield of L-glutaminase is elucidated in Fig. 10. The highest yield of enzyme was recorded with malt extract $156 \pm 1.17 \mathrm{IU} / \mathrm{gds}$ compared to other nitrogen sources used in this study.

\section{Effect of L-glutamine concentration}

In the present study, the highest production of L-glutaminase $138 \pm 1.67 \mathrm{IU} / \mathrm{gds}$ by Halomonas elongata MM- 5 was observed at $1.5 \%$ of L-glutamine concentration and the least $98 \pm 1.48 \mathrm{lU} / \mathrm{gds}$ at $3 \%$ concentration. The production of L-glutaminase showed a linear enhancement along with the rise in substrate concentration up to $1.5 \%$ level (Fig. 11). However, no enhancement in enzyme production was observed after enhancing the L-glutamine concentration above $1.5 \%$.

\section{Inoculum Size}

The production of L-glutaminase varied with inoculum level and showed the highest enzyme production $159 \pm 1.46 \mathrm{lU} / \mathrm{gds}$ at 4 percent of inoculum size (Fig. 12). At higher and lower inoculum levels, less enzyme yield was reported. It is very necessary to inoculate a required volume of inoculum in the fermentation process. The less inoculum volume may not produce enough biomass and results in decreased product synthesis. Whereas a surplus density of inoculum may result in excessive biomass production that decreases the availability of nutrients or accumulates some non-volatile compounds which inhibit the formation of product (Kashyap et al. 2002).

All the studied physicochemical parameters were having more or less influence on the production of Lglutaminase by Halomonas elongata MM-5. After the screening a mixture of solid substrates and optimization of various parameters, the yield of L-glutaminase increased from 79.03 to $159.12 \mathrm{lU} / \mathrm{gds}$ under SSF.

\section{Conclusions}

The present study was focused to evaluate the suitability of various agro-industrial byproducts and different physicochemical conditions for L-glutaminase production. All the investigational consequences of this study justify that red gram husk and bengal gram husk in (60:40) ratio are the best very low-cost substrates for L-glutaminase production by Halomonas elongata MM-5.

\section{Declarations}

\section{Acknowledgement}


The authors are thankful to the Department of Biotechnology, COCSIT, Latur, M.S, India for providing infrastructure and necessary facilities.

\section{Compliance with ethical standards}

Conflict of interest The authors declare that they do not have any conflict of interest.

Ethics approval and consent to participate "Not applicable"

Consent for publication "Not applicable"

Availability of data and materials "Not applicable"

Competing interests All three authors declare that they have no competing interests.

\section{Funding "Not applicable"}

\section{Authors' contributions}

This research work was performed in teamwork by all three authors. The first draft of the research article is designed and written by the Author MM. The experimental work of this study and statistical analyses of data obtained was carried out by Author DGJ and MM both. Author BMK supported to design this investigation and drafted the manuscript. The final manuscript is checked and approved by all three authors.

\section{References}

1. Amulya Y, Raju K J (2014). Production of L-Glutaminase by Aspergillus wentii MTCC 1901 using mixed agro residues tea dust and green gram under solid state fermentation. Journal of Chemical, Biological and Physical Sciences 5:320-330.

2. Amobonye A, Singh S, Pillai S (2019). Recent advances in microbial glutaminase production and applications-a concise review. Crit Rev Biotechnol 39:944-963. https://doi.org/10.1080/07388551.2019.1640659

3. Athira R, Elizebeth T, Narendra T, Sheik T, Gupta S, Chaudary M, Siddalingeshwara K, Pramod T (2014) Investigation on the production of L-glutaminase from Pseudomonas stutzeri strain under solid state fermentation using various agro residues. J Drug Del Therap 4:81-85. http://jddtonline.info/index.php/jddt/article/view/814

4. Bajar S, Singh A, Bishnoi N R (2020) Exploration of low-cost agro-industrial waste substrate for cellulase and xylanase production using Aspergillus heteromorphus. Appl Water Sci 10:153. . https://doi.org/10.1007/s13201-020-01236-w

5. Bhosale H, Sukalkar S, Uzma md Z, Kadam T (2011) Production of xylanase by Streptomyces rameus grown on agricultural wastes. Biotechnol Bioinf Bioeng 1:505-512. 
6. Bhosale H, Uzma md Z, Bismile PC (2015) Optimization of lipase production by thermo-alkalophilic Bacillus sp.8C Research Journal of Microbiology. 10:523-532.

7. Botella C, Diaz A, de Ory I, Webb C, Blandino A (2007) Xylanase and pectinase production by Aspergillus awamori on grape pomace in solid state fermentation. Process Biochemistry 42: 98-101. https://doi.org/10.1016/j.procbio.2006.06.025

8. ElSayed ASA (2009) L-glutaminase production by Trichoderma koningii under solid state fermentation. Ind J Microbiol 49:243-250. https://doi.org/10.1007/s12088-009-0020-2

9. Hiremath J, Kumar S, Rathod V (2011) Production of L-Glutaminase by Pseudomonas VJ-6. Res J Biotech 6:42-49.

10. Hölker U, Lenz J (2005) Solid-state fermentation-Are there any biotechnological advantages? Curr Opin Microbiol 8:301-306. https://doi.org/10.1016/j.mib.2005.04.006

11. Imada A, Igarasi S, Nakahama K, Isono M (1973) Asparaginase and glutaminase activities of microorganisms. J Gen Micro 76:85-99. https://doi.org/10.1099/00221287-76-1-85.

12. Kashyap P, Sabu A, Pandey A, Szakacs G and Soccol CR (2002) Extracellular L-glutaminase production by Zygosaccharomyces rouxii under solid-state fermentation. Process Biochemistry 38: 307-312. https://doi.org/10.1016/S0032-9592(02)00060-2

13. Marzo C, Díaz AB, Caro I, Blandino A (2019) Valorization of agro-industrial wastes to produce hydrolytic enzymes by fungal solid-state fermentation. Waste Management \& Research 37:149-156. https://doi.org/10.1177/0734242X18798699

14. Mathioudakis V, Gerbens-Leenes PW, Van der Meer TH, Hoekstra AY (2017) The water footprint of second-generation bioenergy: A comparison of biomass feedstocks and conversion techniques. Journal of Cleaner Production 148:571-582. (10.1016/j.jclepro.2017.02.032)

15. Mohammed Mujahed, Kareppa BM, Nilesh V More, Tarte SH (2019a) Optimization of fermentation conditions for L-glutaminase production by marine halotolerant Pseudomonas aeruginosa MM-2. Think India Journal 22:811-819.

16. Mohammed Mujahed, Kareppa BM, Tarte SH (2019b) Optimization of physicochemical parameters to enhance the production of L-glutaminase by Pseudomonas aeruginosa MM2 under SSF. J Mycol PI Pathol 49:368-373.

17. Mohana S, Acharya BK, Madamwar D (2008) Distillery spent wash: Treatment technologies and potential applications. J Hazard Mater 163:12-25. (DOI: 10.1016/j.jhazmat.2008.06.079)

18. Mosallatpour S, Aminzadeh S, Shamsara M, Hajihosseini R (2019) Novel halo- and thermo-tolerant Cohnella sp. A01 L-glutaminase: heterologous expression and biochemical characterization. Sci Rep 9:1906. https://doi.org/10.1038/s41598-019-55587-9

19. Nandakumar R, Yoshimune K, Wakayama M, Mitsuaki M (2003) Microbial glutaminase: biochemistry, molecular approaches and applications in the food industry. $\mathrm{J}$ Mol Catal B: Enzym 23:87-100.

20. Pandian B (2015) Extracellular production and purification of bacterial L-glutaminase and evaluation of its anti-cancer potential. Kalasalingam University. 
21. Pandey A (2003) Solid-state fermentation Biochem Eng J 2003, 13:81-84. https://doi.org/10.1016/S1369-703X(02)00121-3

22. Prabhu GN and Chandrasekaran M (1997) Impact of process parameters on L-glutaminase production by marine Vibrio costicola under solid state fermentation using polystyrene as inert support. Process Bioch 32:285-289. https://doi.org/10.1016/S0032-9592(96)00083-0

23. Ravindran R, Hassan SS, Williams GA, Jaiswal AK (2018) A Review on bioconversion of agroindustrial wastes to industrially important enzymes. Bioengineering (Basel). 5: 93 (DOI: 10.3390/bioengineering5040093)

24. Sandhya Xavier and Lonsane BK (1994) Factors influencing fungal degradation of total soluble carbohydrates in sugar cane pressmud under solid state fermentation. Process Biochemistry 29:295301. https://doi.org/10.1016/0032-9592(94)80072-3

25. Sathish T, Laxmi GS, Rao Ch S, Brahmaiah P and Prakasham RS (2008) Mixture design as first step for improved glutaminase production in solid-state fermentation by isolated Bacillus. Let App Microbiol 47:256-262. https://doi.org/10.1111/j.1472-765X.2008.02413.x

26. Saxena R, Singh R (2011) Amylase production by solid-state fermentation of agro-industrial wastes using Bacillus sp. Braz J Microbiol 42:1334-1342. https://doi.org/10.1590/S1517838220110004000014

27. Sodhi HK, Sharma K, Gupta JK and Soni SK (2005) Production of a thermostable a amylase from Bacillus sp. PS-7 by solid state fermentation and its synergistic use in the hydrolysis of malt starch for alcohol production Process Biochemistry 40:525-

534. https://doi.org/10.1016/j.procbio.2003.10.008

28. VivekBabu CS, Lingappa K (2004) Optimization of fermentation conditions for lovastatin production in solid state fermentation using Aspergillus terreus KLVB 28. Bio Biotech Bioent 291- 297.

29. Yazid NA, Barrena R, Komilis D, Sanchez A (2017) Solid-state fermentation as a novel paradigm for organic waste valorization: A review. Sustainability 9:224 https://doi.org/10.3390/su9020224

\section{Figures}

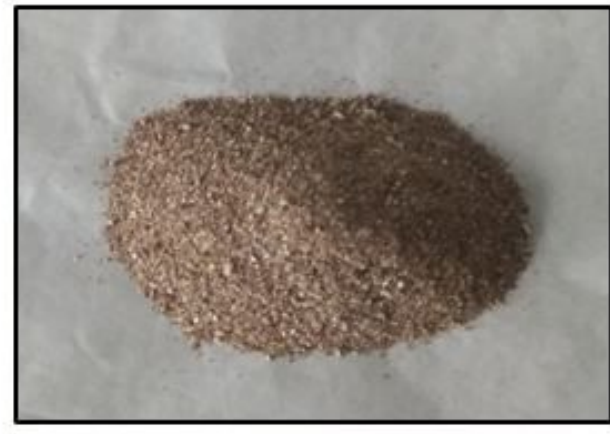

Black gram husk

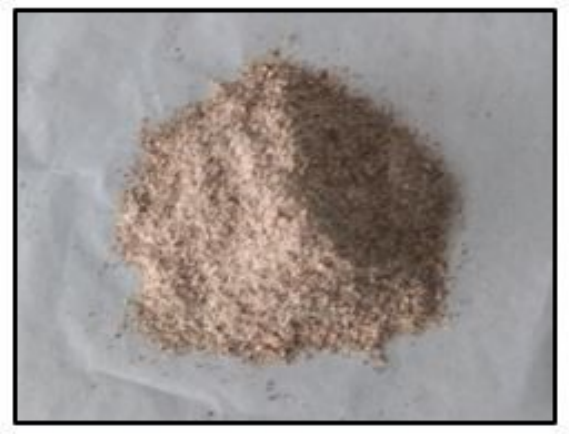

Red gram husk

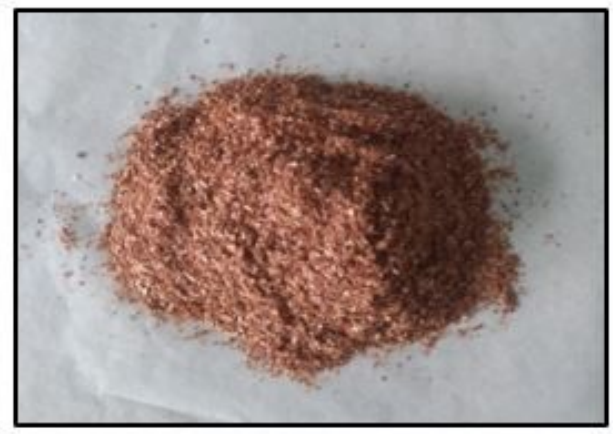

Groundnut skin 
Substrates for the production of L-glutaminase.

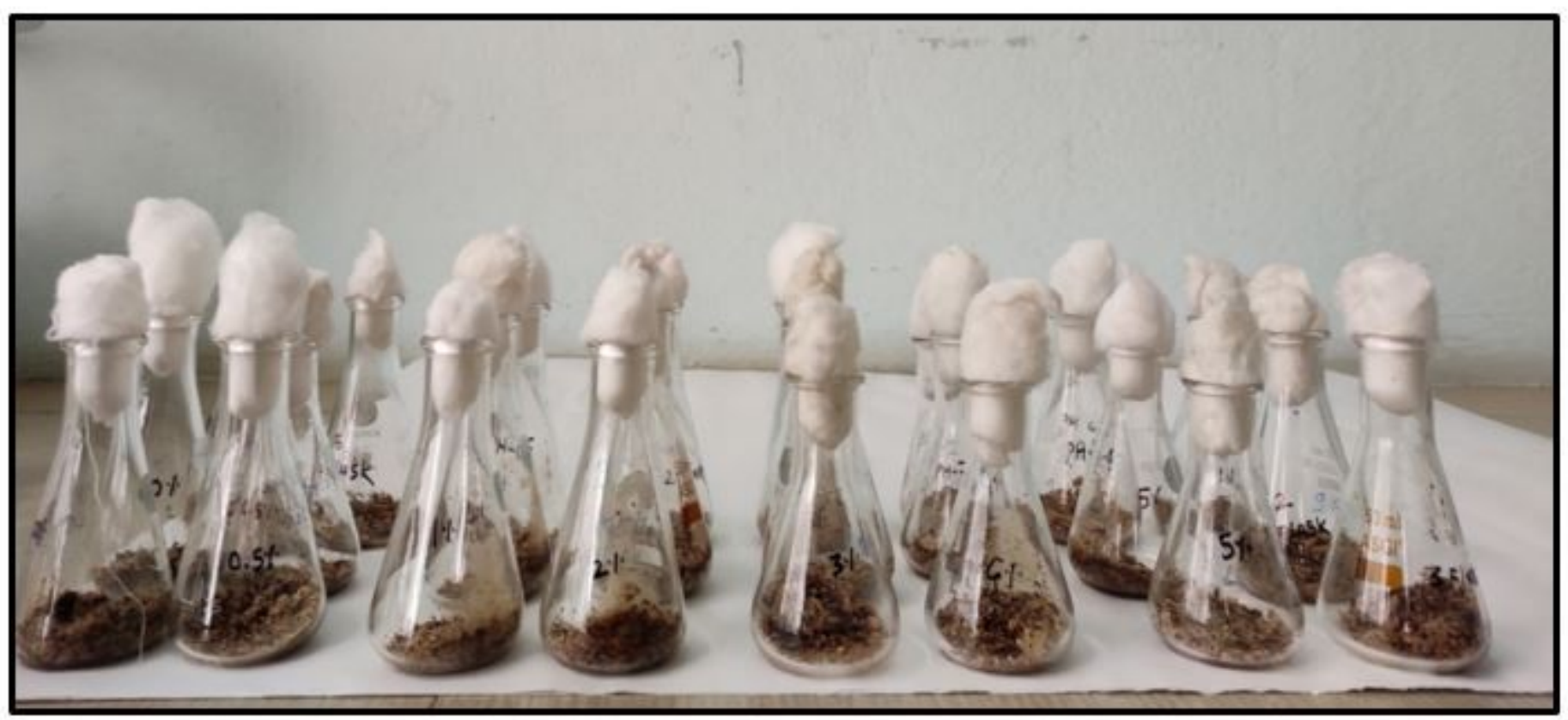

Figure 2

Production of L-glutaminase under SSF.

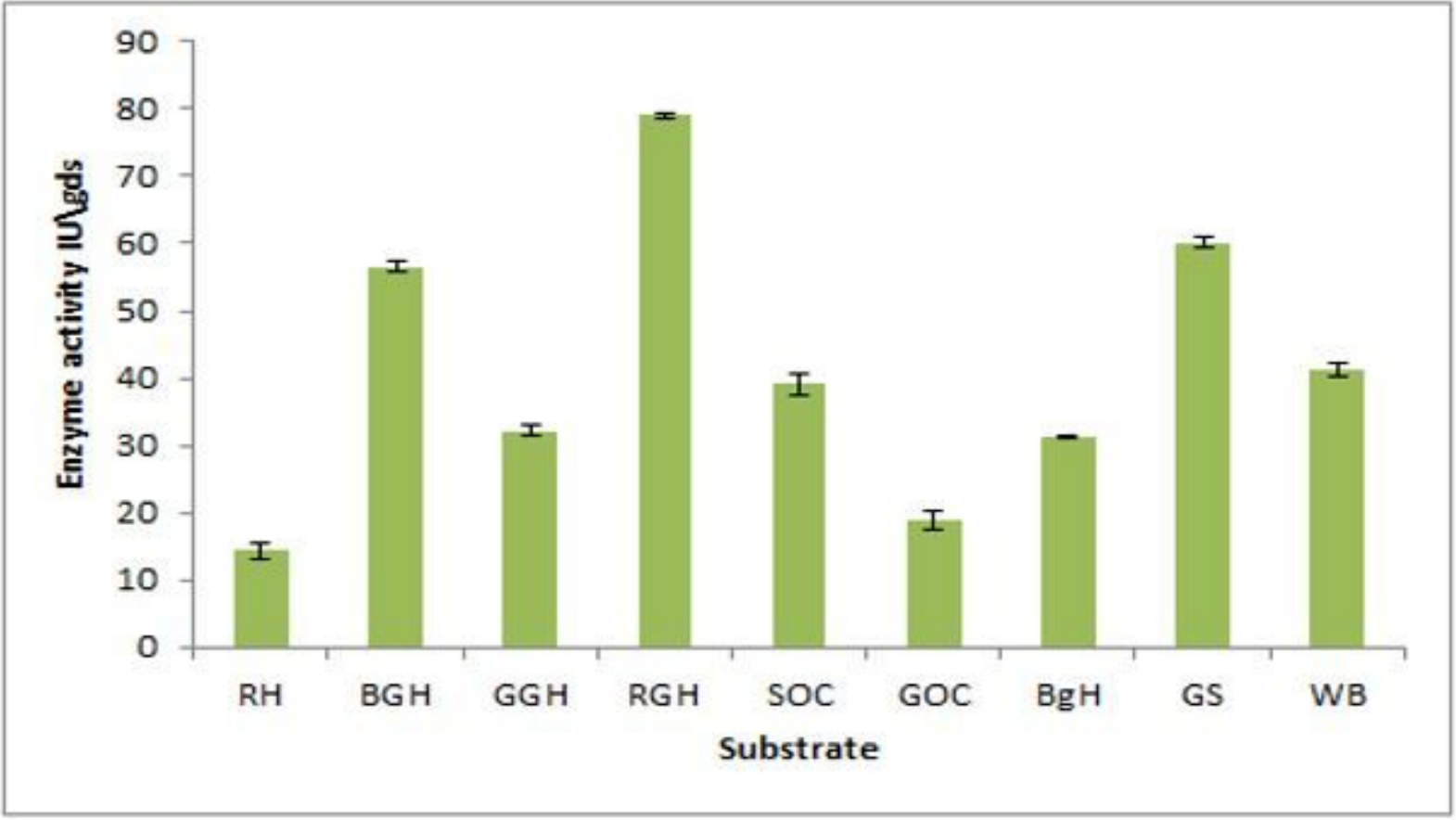

Figure 3

Screening of various substrates for L-glutaminase production under SSF. 


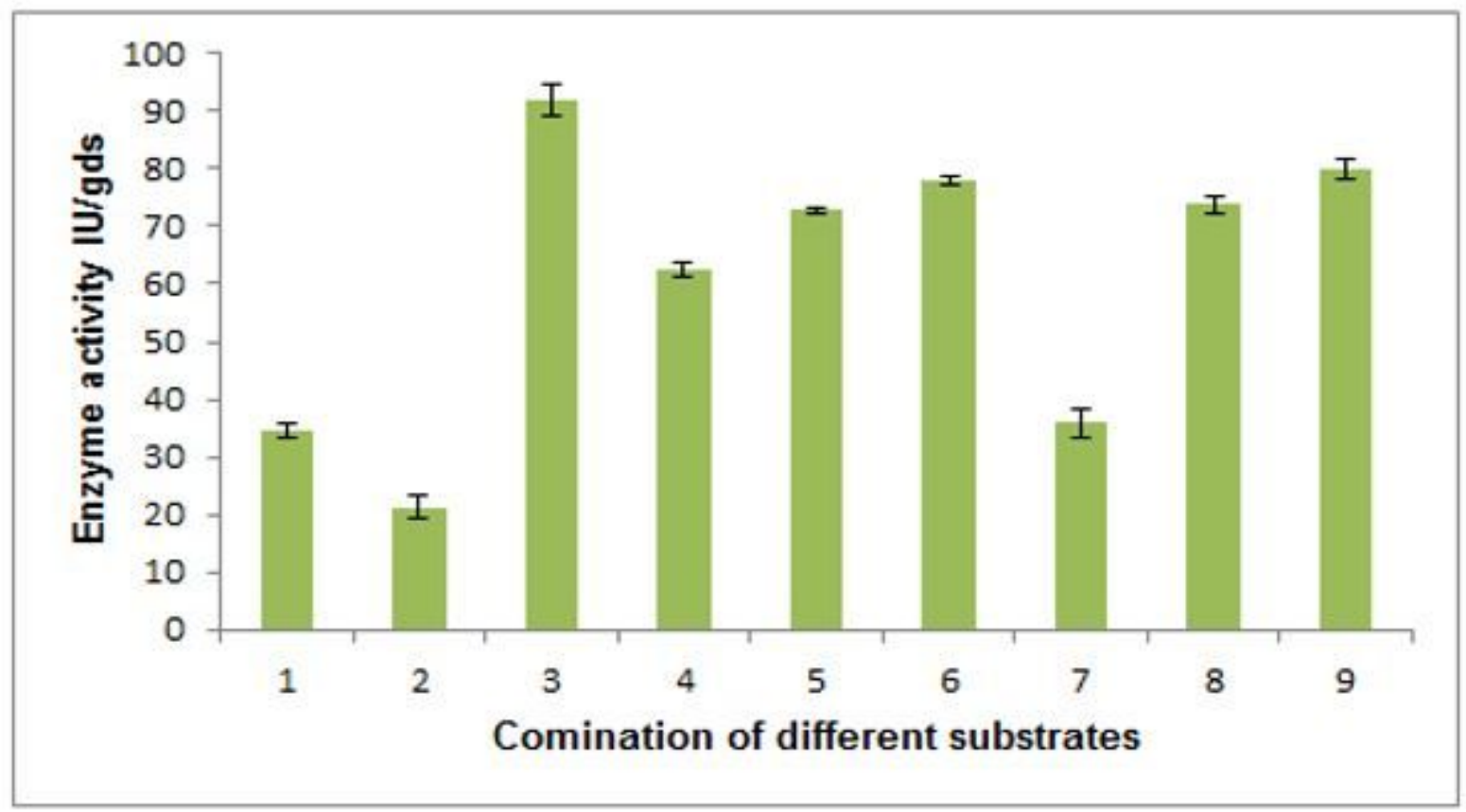

Figure 4

Screening of mixed substrates for L-glutaminase production under SSF.

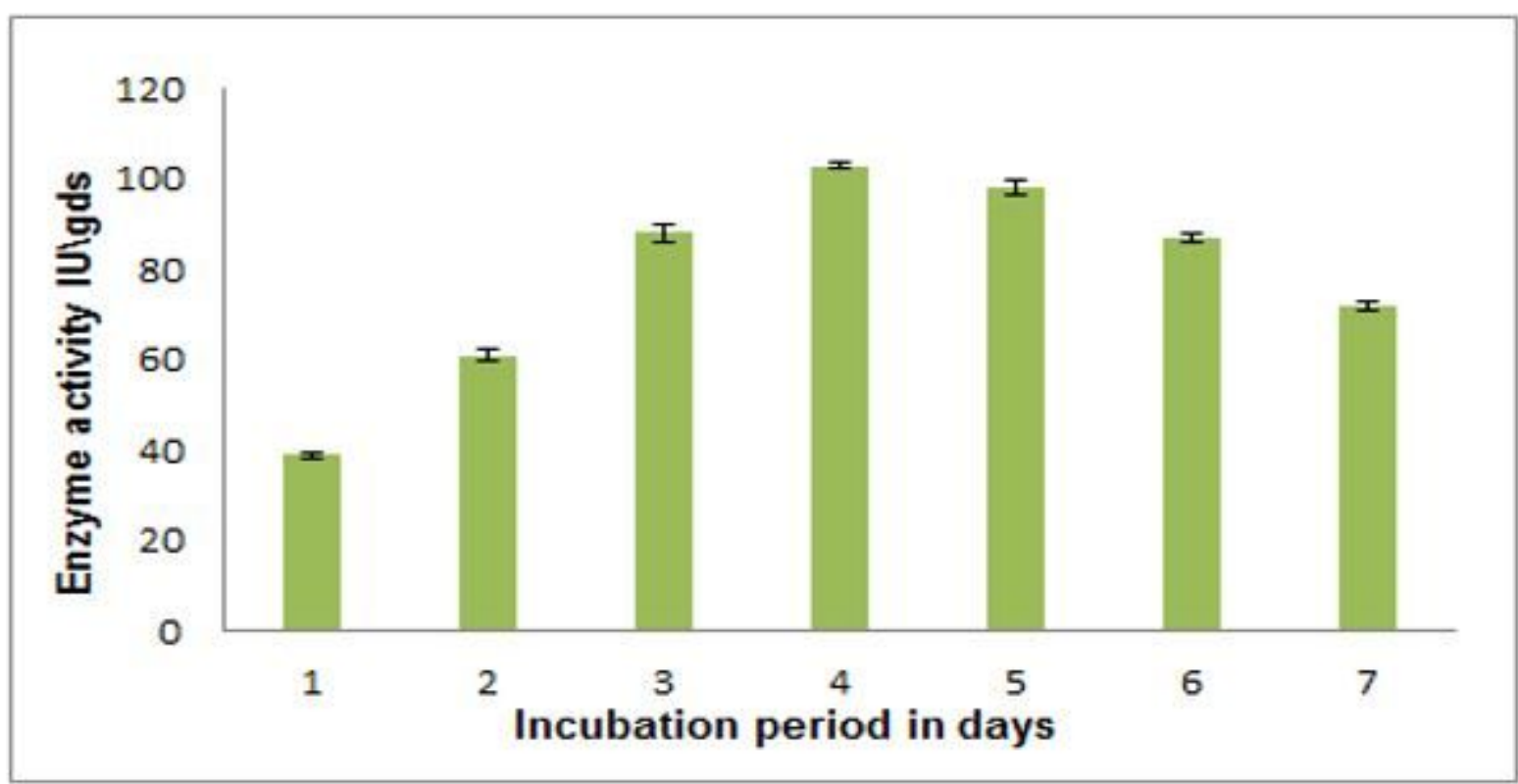

Figure 5

Effect of Incubation period on the production of L-glutaminase. 


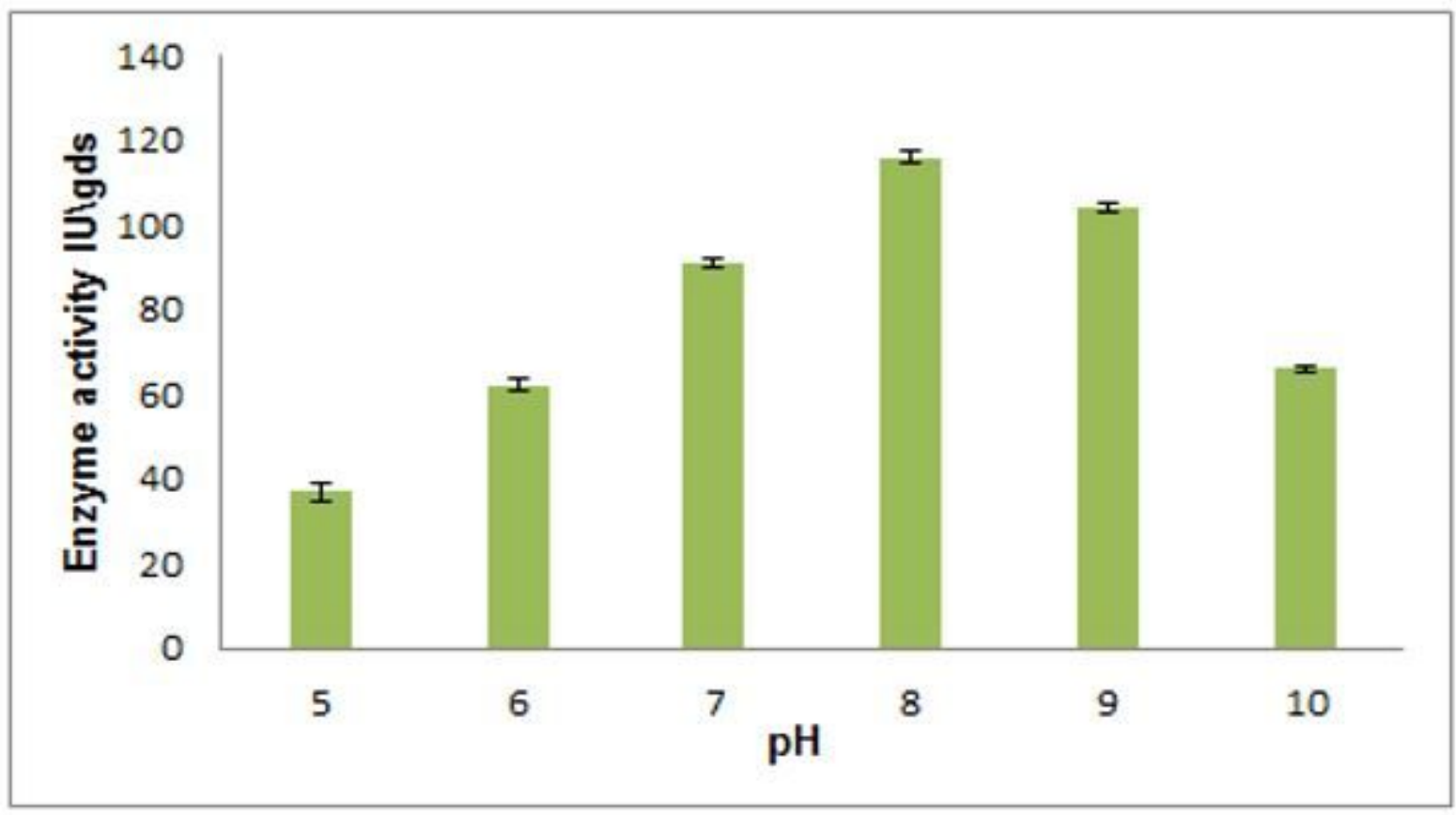

Figure 6

Effect of $\mathrm{pH}$ on the production of L-glutaminase.

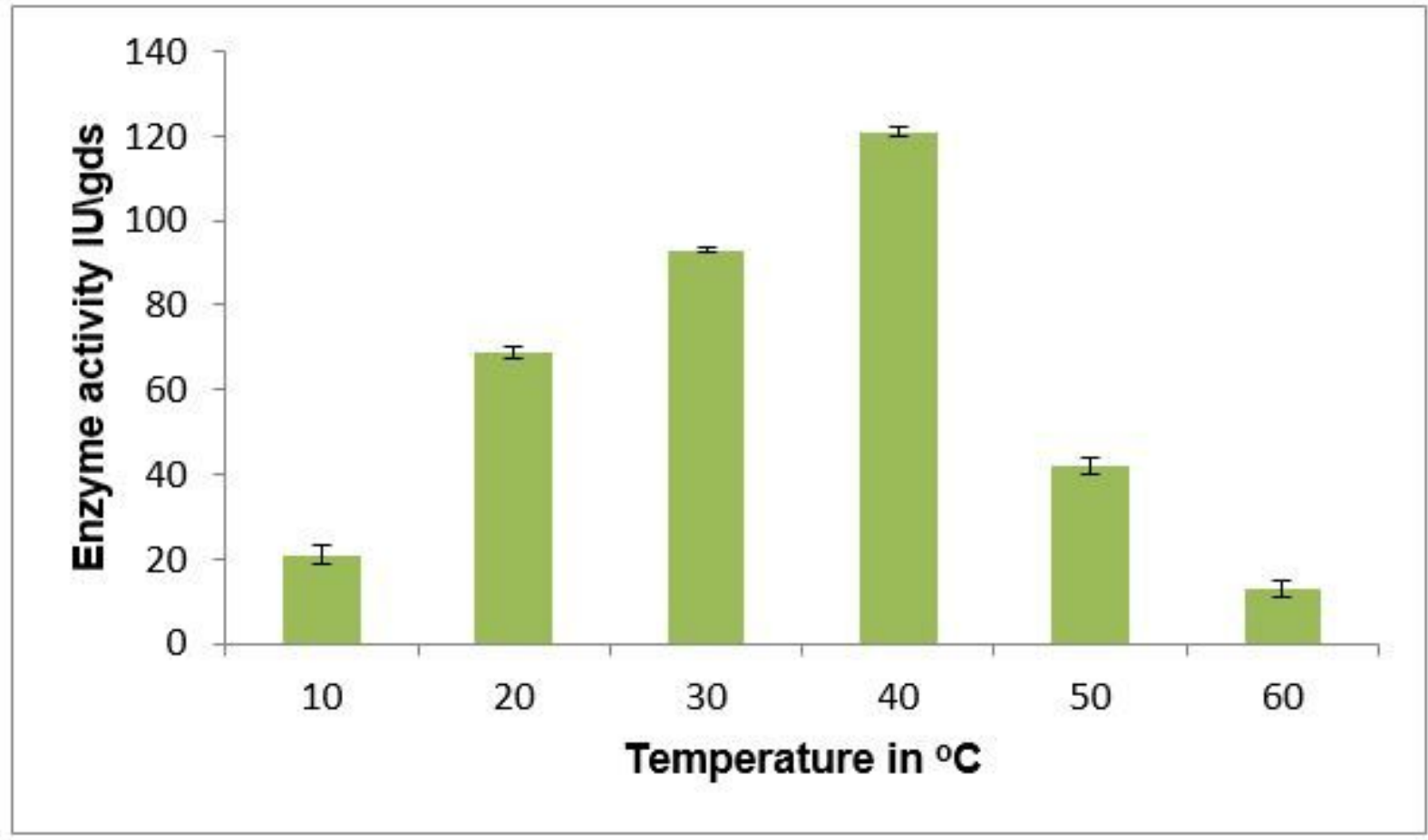

Figure 7

Effect of temperature on production of L-glutaminase. 


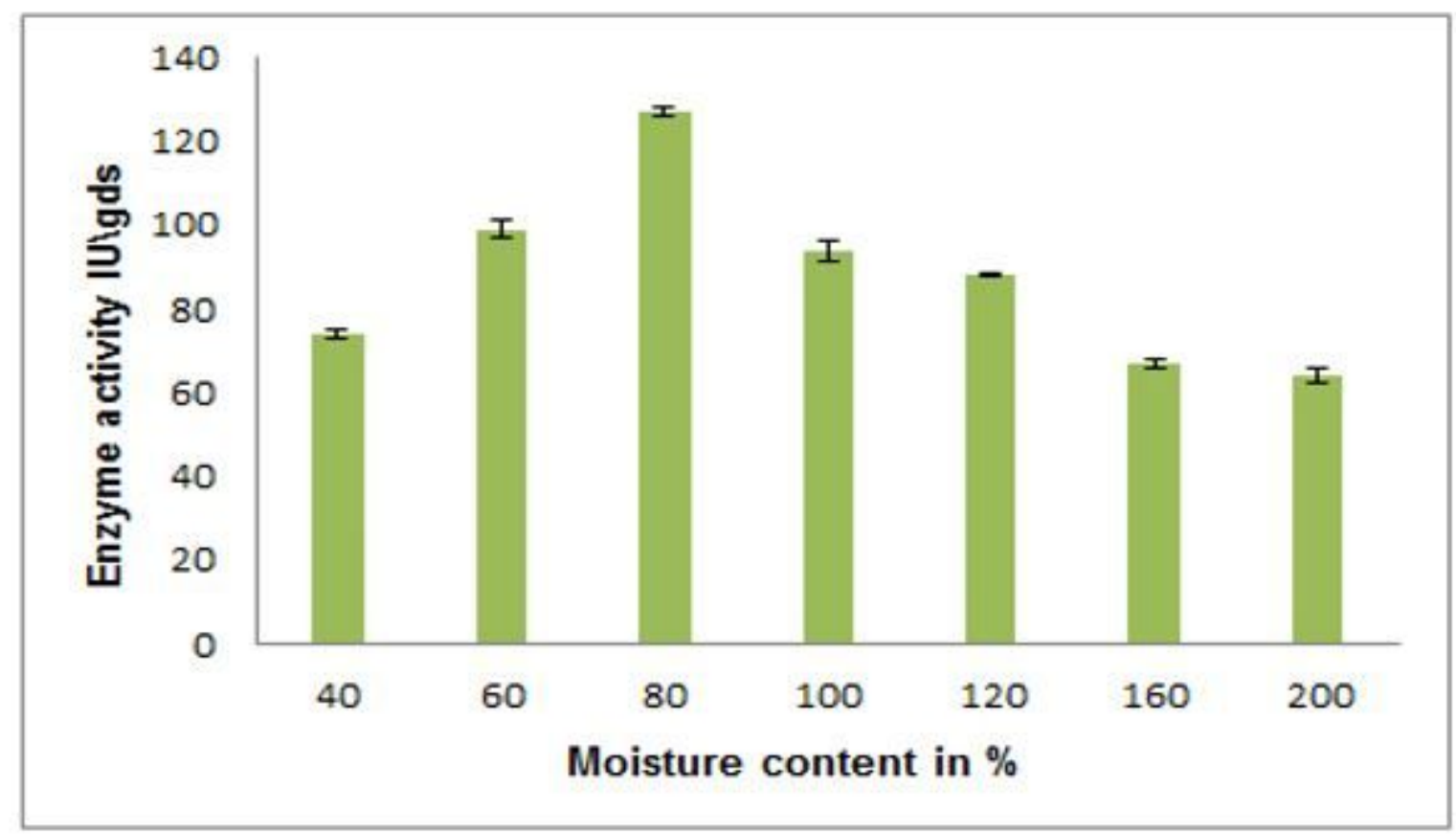

Figure 8

Effect of moisture content on the production of L-glutaminase.

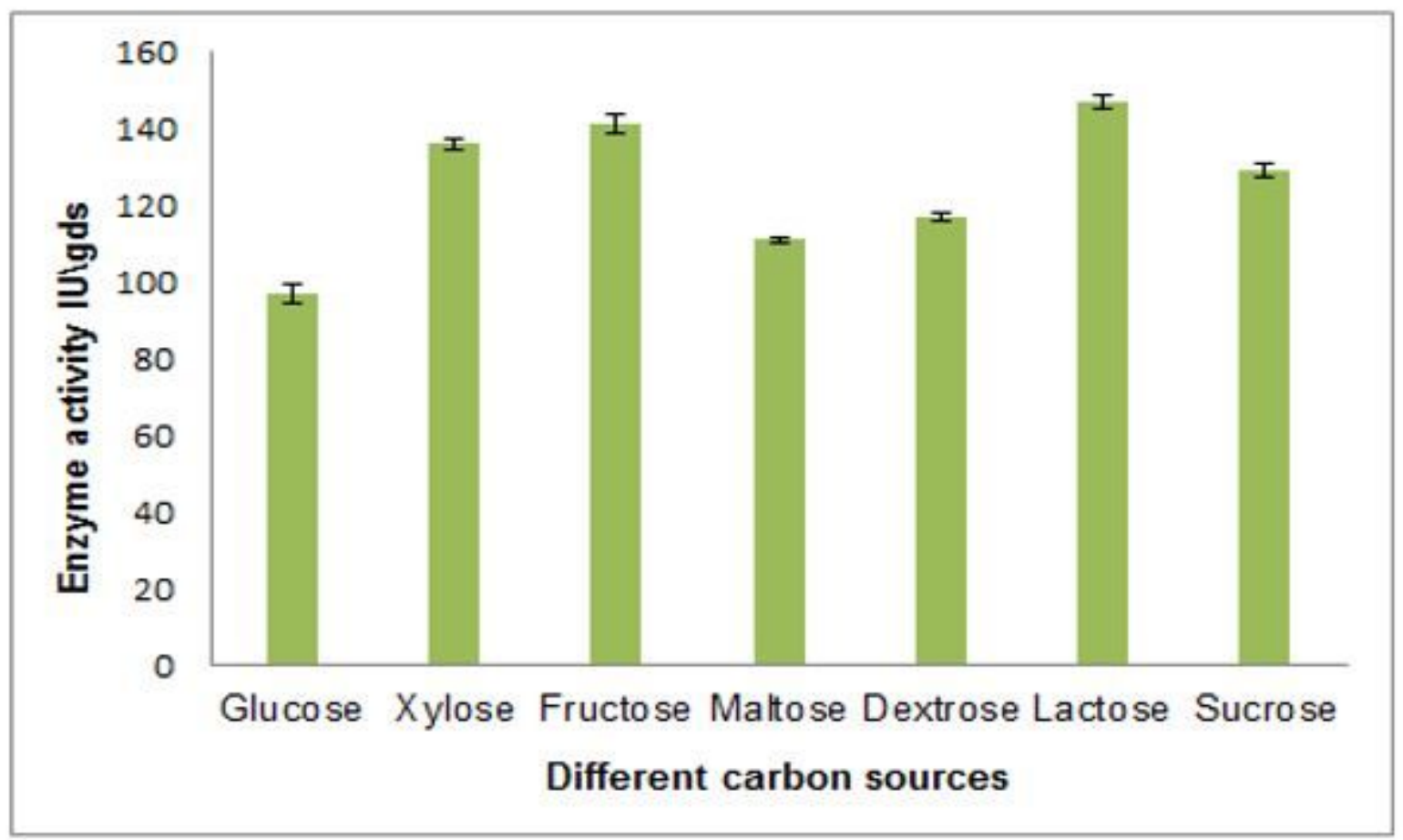

Figure 9

Effect of different carbon sources on the production of L-glutaminase. 


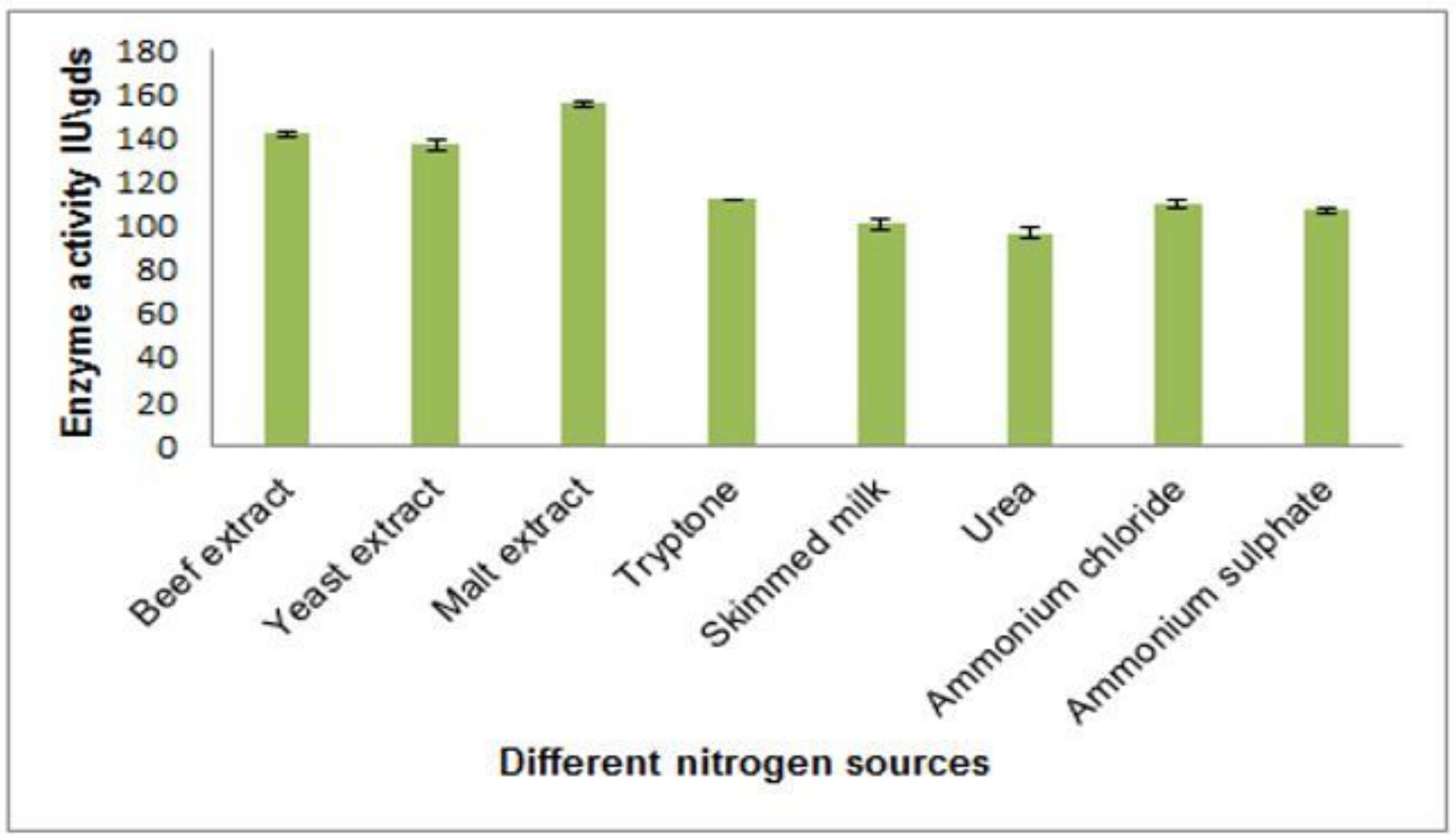

Figure 10

Effect of nitrogen sources on the production of L-glutaminase.

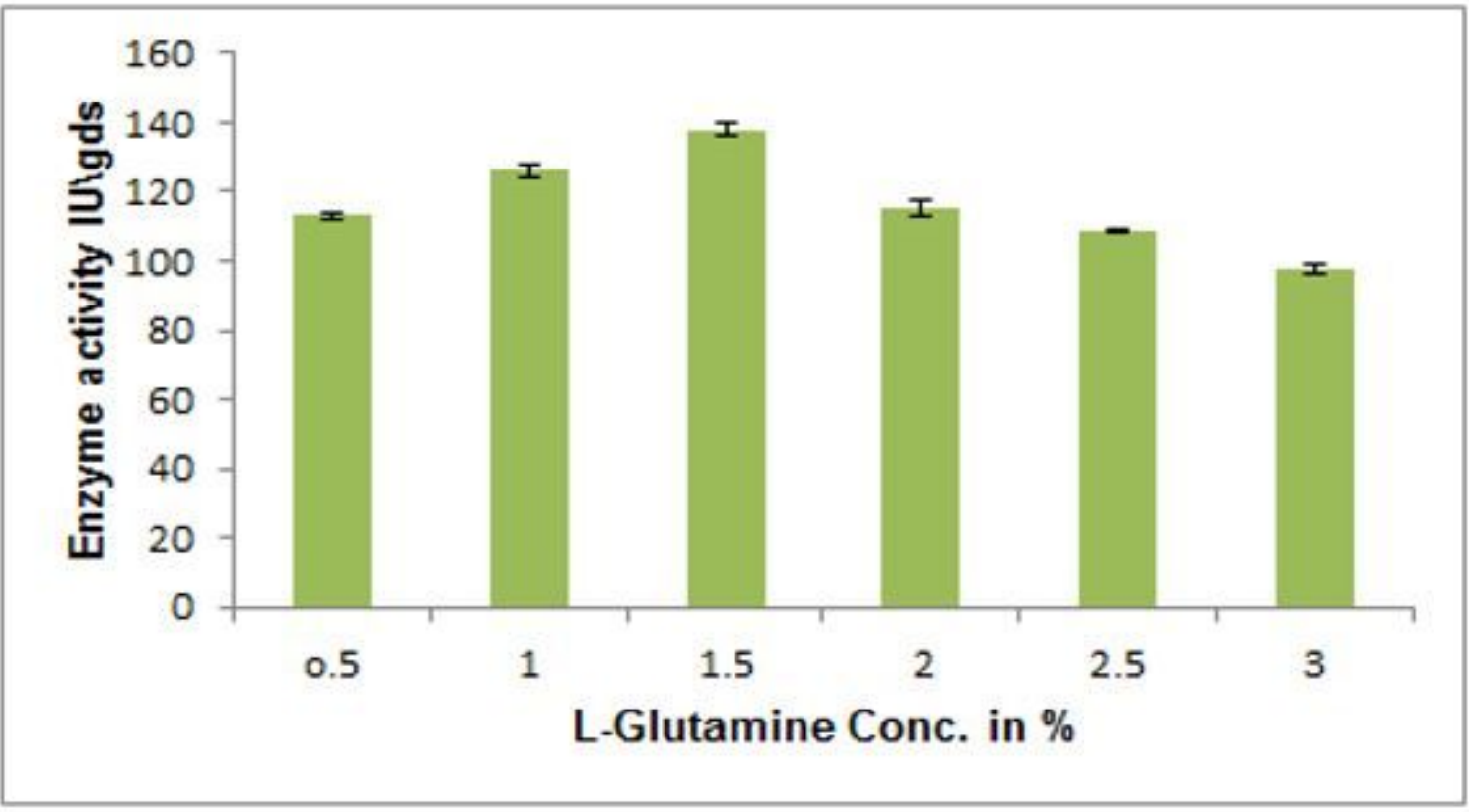

Figure 11

Effect of L-Glutamine Conc. on the production of L-glutaminase. 


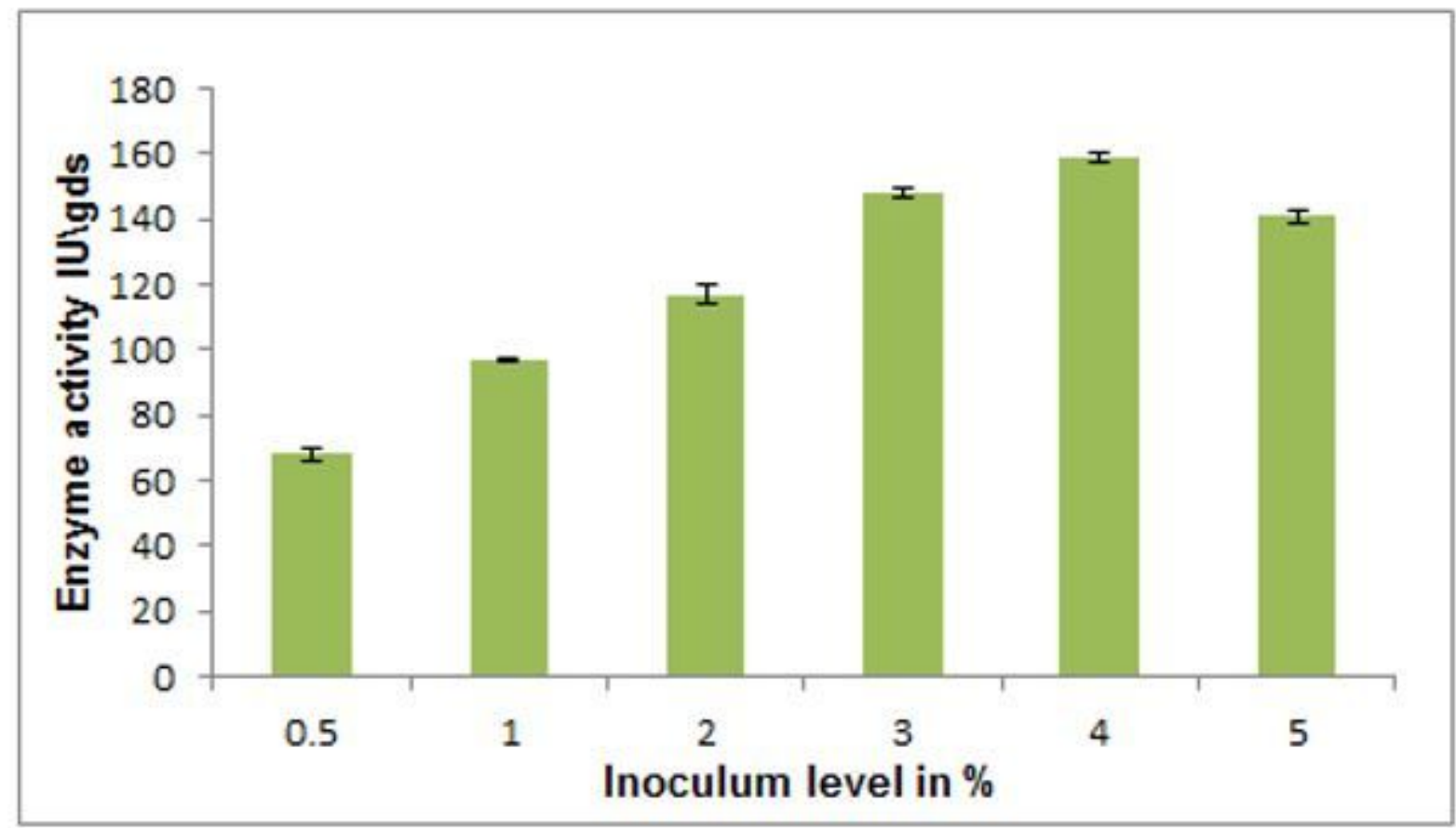

Figure 12

Effect of Inoculum level on the production of L-glutaminase. 